16 per cent in 1957-58 and 19 per cent in 1961-62. In 1952-53 agricultural and veterinary sciences accounted for 42 per cent of the total, but in 1961-62 for only 30 per cent, whereas the Council for Scientific and Industrial Research and the Atomic Energy Establishment together accounted for 36 per cent, railways and defence for 5 per cent, and medical for 7 per cont. Research expenditure by the States is mainly on agricultural and veterinary research (79 per cent in 1961-62), while most industrial research is supported by the Central Government, mainly by the Council for Scientific and Industrial Research (Rs. 81 million out of Rs. 85 million in 1961-62). The Central Government was also responsible for more than 89 per cent of the Rs. 22 million on the Geological Survey in 1961-62 and for Rs. 20 million out of the Rs. 33.8 million expended on medical research; practically all the Rs. 13.9 million spent on irrigation and power in 1961-62 came from the Central Government, and of Rs. 87 million spent on research in nuclear energy in 1961-62, Rs. 28 million was capital expenditure. Research expenditure in India in 1961-62 is estimated as 0.32 per cent of the gross national product, compared with 0.12 per cent in $1952-53$, and as Rs. 16,800 on each of 37,000 scientists in 1962 .

The Museum of Applied Arts and Sciences, Sydney

WITH the usual attractive cover design the annual report for 1962 of the Museum of Applied Arts and Sciences in Sydney mentions the disappointment of the Trustees in that they cannot record the commencement of work on the renovation of the Old Ultimo Tramway Depot for a Transport Museum (Pp. 28. Sydney: Museum of Applied Arts and Sciences, 1963). The Trustees have already assembled a unique collection of items, including historic locomotives, trams, cars, aeroplane-engines and aircraft as well as an outstanding collection of bicycles, and it is hoped that accommodation for these will be provided in the near future. The planetarium continues to be very popular and the seating capacity of $30-35$ people only enables a fraction of those wishing to see it to be admitted although sessions are almost continuous. In a few years the useful life of the projector will be completed and consideration has already been given to the purchase of a new and larger apparatus.

\section{Public Administration in French}

French Bibliographical Digest is intended primarily to make the contributions of French scholars better known in the United States. No. 38, Series II, 1963, is devoted to studios in France during the past five years in public administration (Pp. 208. New York, N.Y.: The Cultural Center of the French Embassy, 1963). It is compiled by B. Gournay and is concerned solely with public administration in metropolitan France, the first part covering general studies and the second the central administration. There appears to be no reference to scientific policy or relations between science and Government-Piganiol and Villecourt's book, Pour une Politique Scientifique, is omitted-but there is a short author index.

\section{Education in Chemistry}

THE now journal, Education in Chemistry, which is to be published quarterly by the Royal Institute of Chemistry, is timely and very welcome (1, No. 1; January 1964. Pp. 1-60+xx. Published quarterly. London: Royal Institute of Chemistry, 1964. Annual subscription, 408 .; 7 dollars). It does not need the Robbins Report or modern information and communication theories to underline the need for a new approach to the problems of what is to be taught and how it should be taught in the scientific subjects at a high educational lovel. These matters need to be assessed constantly, in terms of individual and social needs, the ever-increasing corpus of knowledge and all the skill and equipment of the modern teacher. There is an account of the projected scheme for the teaching of chemistry in the University of Sussex by Prof. C. Faborn.
This seems excellent and should do much to neutralize the bad impression of a course of lectures on another subject, which were televised from the sqme institution and would have been better had they been given as a printed booklet to the students. The aims and methods so ably described by Prof. Eaborn might well be considered elsewhere and for other subjects. If university teachers will persist in using their lectures for merely conveying information, with students scrambling to take down notes from the fleeting and often elusive word, they will have to show why their method is a more effective use of the students' time than the reading of the lecture material in printed or duplicated form. The functions and interaction of lecture, class, seminar and tutorial session must be considered. The publication contains authoritative articles on education in chemistry and a number of chapters on the use of structures and models in teaching. There are also reviews of books, films and apparatus, a discussion forum and a foreign section. Altogether, it is a very useful magazine.

\section{Vocational Education and Training in the U.S.S.R.}

THE British Association for Commercial and Industrial Education has published a report by P. J. C. Perry, entitled Vocational Education and Training in the Soviet Union (British Association for Commercial and Industrial Education. Vocational Education and Training in the Soviet Union: Report of the BACIE Delegation's Visit, May 5-23, 1963. Compiled from the Delegation's Notes by P. J. C. Perry. Pp. 60 . London: British Association for Commercial and Industrial Education, 1963. 21s.; B.A.C.I.E. members $14 s$.). The report was compiled from notes of a visit by a Delegation of the Association during May 5-23, 1963. The delegation was particularly impressed by the absolute conviction in the U.S.S.R. of the value of education and training: 16 per cent of the national budget is spent on edueation with first priority to education and training. Mr. Perry first describes the ideological background and then, in short successive chapters, the organization of secondary education, vocational training, the training of foremen and technicians, the system of higher education, and the use of grants and scholarships and correspondence courses. One on the teaching of foreign languages is followed by others on teachers, management and economic studies, buildings and the place of women in the Soviet economy. The constitutional framework is outlined in an appendix, and there are some suggestions for further reading. There is much in the report of interest to those involved in the present debates in Britain on education and on industrial training. It might be noted that there is no apprenticeship in the British sense; no age-limit to training or re-training; no restricted entry save for the requirements of the economic plan; and a highly concentrated and intensive basic period of vocational training covering a maximum of throe years, with regular tests on performance loading to standard tests, as well as powerful incontives to further study and up-grading. Promotion to foreman is increasingly made on completion of the full eleven-year period of secondary education and foreman training is done on a part-time basis. Mr. Perry also notes, of grants and scholarships, that in this controlled society, dedicated to egalitarian principles, the carrot of financial incentive seems to have superseded the stick of compulsion.

\section{Training of General Practitioners}

Thene has been, in Britain and other countries, much discussion recently of the training of the general medical practitioner. Most European countries are, like Britain, suffering from a shortage of doctors and from overcrowded medical schools and many feel that the existing methods of training medical students for general practice need revision. The general practitioner occupies a unique 